\title{
Assessment of Work Programs and Performance of Counseling and Career Counseling Centers Kuningan University
}

\author{
Novi Satria Pradja ${ }^{1}$, Myrna Apriany Lestari², Dita Hardiyanti ${ }^{3}$ \\ Kuningan University, Indonesia \\ \{satria.pradja@uniku.ac.id ${ }^{1}$,myrna@uniku.ac.id², dita@uniku.ac.id ${ }^{3}$ \}
}

\begin{abstract}
Kuningan University (UNIKU) has set a vision "By 2032 To Become a Superior University with High Commitment to Community Empowerment". To achieve this, UNIKU needs to take strategic steps, one of which is by providing an excellent service system to students through its Service Units Work Program, especially those directly related to services to students, such as the Counseling and Career Guidance Center with the main task of Coordinating the implementation of guidance and counseling for students who have both academic and non-academic problems as well as providing services for students and alumni in getting jobs and career development. Therefore, PBKK has a work program that includes DPA Training, Psychological Tests for New Students, Career Support for Prospective Graduates, Job Fair, Alumni Association Formation, and Tracer Study. Several programs have been implemented while some have not been implemented due to technical difficulties. In this working period, the PBKK tries to evaluate work programs and performance using an appraisal process. This assessment is carried out by the leadership (Rector and WR 3), peers (Chair of SPM and SPI), as well as student representatives. This performance appraisal adapts the Employee Performance Appraisal Using the 360 Degree Method carried out at STIKOM Dinamika Bangsa Jambi. Based on the results of data processing, the PBB score was 4.2 or it was in a Good category. Meanwhile, the work program is evaluated using the CIPP method. The results of the evaluation show that the PBKK work program is by the context, input, process, and product with the needs of students and the vision and mission the institution wants to achieve
\end{abstract}

Keywords: Assessment of Work Programs and Performance; 360 Degree Method; CIPP Method

\section{Introduction}

In the 2019 Kuningan University Academic Guidance Book, it is explained that the Counseling and Career Guidance Center (PBKK) is an academic support element which has the main task of coordinating the implementation of guidance and counseling for students who have both academic and non-academic problems as well as providing services for students and alumni. in getting a job and in career development. Academic guidance service is a process of assistance provided to students in dealing with academic problems while studying at university so that students can increase their study success which is marked by obtaining a very satisfying Grade Point Average (GPA), completing the study period on time, and being absorbed by the students. graduates in the world of work according to the educational background they have taken. In practice, this academic service is provided by Academic 
Advisors (DPA). The guidance and mentoring takes the form of consultation either on a scheduled basis or based on student needs. The PBKK is tasked with enhancing the role and function of the DPA through the provision of the DPA Handbook, providing training for new DPAs, and receiving reveals for issues that DPA cannot resolve.

In addition to providing services in the academic field, PBKK also plays a role in providing non-academic services, such as helping students face personal problems, family (family problems), peer group problems, learning/academic (learning problems), and career (career problems). One of the non-academic services provided is tracing interests, talents, and self-potential through psychological tests. This service is important to provide to help students develop their potential optimally.

PBKK also oversees the Career Development Unit which is tasked with facilitating students and alumni to increase their understanding and skills towards the demands of the world of work by holding Career Guidance Seminars and Workshops for prospective graduates and connecting alumni with the world of work through the implementation of Job Fair or employee recruitment which is held regularly. independently at university. Two other important PBKK work programs are strengthening alumni ties and conducting tracer studies. Tracer study is a research on the situation of alumni, especially in terms of job search, work situations, and the use of competency gains during their studies at UNIKU.

In developed countries, alumni traceability studies are the main studies that have been carried out systematically, institutionally, and continuously. So it is not surprising that universities in developed countries are recognized for their relevance because universities continuously conduct self-evaluation, among others, through the results of tracer studies. The benefits of a tracer study are not limited to universities, but can further provide important information regarding the link between the world of higher education and the world of work. Tracer studies can provide in-depth and detailed information about work fit both horizontally (between various fields of science) and vertically (between various levels/strata of education). Thus, a tracer study can help overcome the problem of job opportunity gaps and efforts to improve them.

For universities, information on competencies that are relevant to the world of work can help efforts to improve curriculum and learning systems. On the other hand, the industrial world and the world of work can look into higher education institutions through tracer studies and thus can prepare themselves by providing more relevant training for new job seekers. One of the main keys to the success of a tracer study is the level of participation of the alumni so that it is hoped that the alumni can participate actively in the tracer study process. Based on the explanation above, it can be concluded that PBKK has an important role in supporting UNIKU's vision and efforts to improve UNIKU's human resources so that PBKK needs to evaluate work programs and performance given to students so far. This is important to do to improve excellent service to students and achieve the university's vision.

\section{Method}

This research is survey research. According to Sugiyono (2013: 11), the definition of the survey method is "Research conducted using a questionnaire as a research tool carried out in large and small populations, but the data studied is data from samples taken from that population, so that relative incidence, distribution, and the relationship between variables, sociological and psychological " 
The purpose of survey research is to provide a detailed description of the background, characteristics, and characteristics of a case or event of a general nature. And the method used in this research is the descriptive method. This method is used to measure certain social phenomena, then explain them descriptively or narrative. In this study, researchers tried to describe the assessment of work programs and the performance of the Counseling and Career Guidance Center (PBKK) for students of the University of Kuningan.

The population is a generalization area consisting of objects or subjects that have certain characteristic qualities to be determined by researchers to study and then draw conclusions (Sugiyono, 2007: 80) while the sample is part of the number and characteristics possessed by the population so that the sample taken must be correct -really representative to be able to represent the population (Sugiyono, 2007: 81). In this study, the research subject was the Center for Counseling Guidance (PBKK), Kuningan University with the object of research being performance appraisal and the PBKK work program.

The data collection technique used in the study was a questionnaire. According to Sugiyono (2009: 199), a questionnaire is a data collection technique carried out by giving a set of questions or written statements to respondents to answer. The selection of a questionnaire as a data collection tool in this study was based on Sugiyono's opinion which stated that questionnaires were an efficient data collection technique if the researcher knew exactly what variables to measure and what could be expected from the respondents.

The research instrument used in obtaining data to assess the effectiveness of work programs and the performance of the Center for Counseling and Career Guidance (PBKK) for Kuningan University Students was in the form of a questionnaire with a value of 1 for the answer "Yes" and a value of 0 for the answer "No".

\section{Result and Discussion}

The effectiveness of the program can be formulated as the level of target realization which shows the extent to which the program targets have been set (Julia, 2010: 26). Based on the definition of effectiveness, it can be understood that effectiveness is a benchmark for comparing the process carried out with the goals and objectives achieved. A program is said to be effective if the effort or action is carried out in accordance with the expected results. Effectiveness is used as a measure to compare the plans and processes carried out with the results achieved. In this study, the PBB work program that had been implemented was evaluated using the CIPP Model. The CIPP evaluation model is considered the most comprehensive evaluation model because this model emphasizes evaluation as a comprehensive process in the managerial system for evaluating programs. The CIPP evaluation model was developed by Stufflebeam (2007) which explains that "The CIPP Evaluation Model is a comprehensive framework for guiding evaluations of programs, projects, personnel, products, institutions, and systems". This means that the CIPP evaluation model is implemented in four management processes, namely context, input, process, and product.

According to Badrujaman (2011), the main objective of context evaluation is to examine the status of the object as a whole so that it can provide a description of environmental characteristics. In the implementation of information services, evaluation of the context aims to determine whether the old goals and priorities are in accordance with service needs. The formulation of the PBKK work program is based on an analysis of the needs of students as 
service recipients, a description of the tasks and functions listed in the Statute as well as the Academic Guideline, as well as adjustments to the University's needs in realizing the vision and mission that has been set. According to Eko Putra Widoyoko (2014) that the input evaluation component includes: human resources, supporting facilities and equipment, funds or budget, and various procedures and necessary rules.

The human resources placed by the university to manage PBKK have been adjusted with expertise such as appointing the head of the counseling guidance unit is someone who has an educational background of S1 and S2 Counseling Guidance, the head of the unit and career guidance staff is someone who has attended periodic training in career development. Supporting facilities and equipment have been provided properly by the University, as evidenced by the existence of a special office and room for the counseling and career guidance unit that can be visited by students on every working day and hour. Funds and budgets are given for each work program each year.

According to Mbulu (1994/1995: 63), process evaluation is used to help provide and provide feedback information in order to implement decisions, to what extent plans or actions to be carried out to determine the implementation of the program are in accordance with established procedures and schedules. The implementation of activities that have been compiled in the PBKK work program can be evaluated in a process from the suitability of the activity proposals prepared, documentation of activities, and accountability reports for each activity that has been carried out. This was reported to the Vice-Rector 3 in student affairs. This evaluation product evaluation seeks to identify and access outputs and benefits, both planned and unplanned, both short and long term. Both are to help staff keep efforts focused on achieving important benefits and ultimately to help broader user groups measure the success of the effort in achieving targeted needs. However, there are still deficiencies in the PBBK program using the CIPP model, namely, there are technical obstacles in some work programs that allow direct student participation, such as filling in tracer study data, student financial ability to take psychological tests, or implementing job fairs.

Furthermore, the assessment of PBKK performance in this study uses the 360-degree feedback method. The 360-degree feedback method is a process where an employee receives information about how he is assessed by a group of people who interact on a daily basis in his work. 360-degree feedback is also known as multi-rater feedback, multi-source feedback, or multisource assessment. The point is that feedback comes from around the employee, where using 360 degrees means a full circle degree with the employee at the center. Thus, feedback comes from several directions at once, namely from subordinates, colleagues, and superiors. This includes self-assessment.

In modern organizations, the assessment provides an important role mechanism for management to use in explaining performance goals and standards and to motivate individual performance in the future. The performance or in English is performance, namely: work results that can be achieved by a person or group of people in the organization, in accordance with their respective authorities and responsibilities in an effort to achieve the goals of the organization concerned legally, does not violate the law and is in accordance with morals or ethics. Performance measurement needs to be done to find out whether during the performance implementation there are deviations from the predetermined plan, or whether the performance can be carried out according to the specified time schedule, or whether the performance results have been achieved as expected. To carry out this assessment requires the ability to measure performance so that performance measures are needed. The steps in the performance appraisal process are determining what criteria will be assessed and their weights, determining sub-criteria, determining the type of weight of the assessor, determining 
the assessment period, and determining the assessors and employees to be assessed. The following is a performance appraisal questionnaire used in this study.

Table 1. UNIKU PBKK Performance Assessment Questionnaire

\begin{tabular}{|c|c|c|c|c|c|c|}
\hline & \multirow{2}{*}{ Indicator } & \multicolumn{5}{|c|}{ Respondents } \\
\hline & & 1 & 2 & 3 & 4 & 5 \\
\hline \multirow[t]{4}{*}{1.} & $\begin{array}{l}\text { Quality of Work (refers to accuracy and margin } \\
\text { of error) }\end{array}$ & & & & & \\
\hline & 1a. Doing a job with great care and calculation & & & & & \\
\hline & $\begin{array}{l}\text { 1b. The abilities that are owned are in accordance } \\
\text { with the work being done }\end{array}$ & & & & & \\
\hline & 1c. Every job is done as ordered & & & & & \\
\hline \multirow[t]{4}{*}{2.} & Work Quantity (refers to the number of results) & & & & & \\
\hline & $\begin{array}{l}\text { 2a. The level of achievement of the resulting } \\
\text { work volume is in accordance with the } \\
\text { expectations of the institution }\end{array}$ & & & & & \\
\hline & $\begin{array}{l}\text { 2b. Work targets have been completed faster than } \\
\text { expected }\end{array}$ & & & & & \\
\hline & $\begin{array}{l}\text { 2c. Can do several tasks according to the priority } \\
\text { scale }\end{array}$ & & & & & \\
\hline \multirow[t]{4}{*}{3.} & $\begin{array}{l}\text { Punctuality (refers to the completion of the task, } \\
\text { within the time allowed) }\end{array}$ & & & & & \\
\hline & $\begin{array}{l}\text { 3a. Able to work in accordance with standards } \\
\text { and regulations }\end{array}$ & & & & & \\
\hline & 3b. Always finish work on time & & & & & \\
\hline & $\begin{array}{l}\text { 3c. Reporting the results of each work to } \\
\text { superiors }\end{array}$ & & & & & \\
\hline \multirow[t]{4}{*}{4.} & $\begin{array}{l}\text { Job Adjustment (refers to the adaptation process } \\
\text { and flexibility in work) }\end{array}$ & & & & & \\
\hline & $\begin{array}{l}\text { 4a. Able to prioritize more important and urgent } \\
\text { work }\end{array}$ & & & & & \\
\hline & $\begin{array}{l}\text { 4b. To produce a practical job, try to be proactive } \\
\text { in finding new work procedures }\end{array}$ & & & & & \\
\hline & $\begin{array}{l}\text { 4c. Can quickly adjust to new decisions made by } \\
\text { the institution }\end{array}$ & & & & & \\
\hline \multirow[t]{4}{*}{5.} & $\begin{array}{l}\text { Responsibilities (refers to the completion of tasks } \\
\text { and work programs) }\end{array}$ & & & & & \\
\hline & $\begin{array}{l}\text { 5a. Always be accountable for every job given to } \\
\text { superiors }\end{array}$ & & & & & \\
\hline & $\begin{array}{l}\text { 5b. Doing work by giving all the capabilities that } \\
\text { are owned according to the procedure }\end{array}$ & & & & & \\
\hline & $\begin{array}{l}\text { 5c. When working, willing to take risks and think } \\
\text { hard to get good results }\end{array}$ & & & & & \\
\hline & $\begin{array}{l}\text { Cooperation (refers to the ability to cooperate and } \\
\text { communicate with other colleagues) }\end{array}$ & & & & & \\
\hline & 6a. Always work in accordance with the corridor & & & & & \\
\hline
\end{tabular}


of the organizational structure (Institution)

6b. Can work well in teams and work together

6c. Act politely or comply with social norms in

the work environment

Information:

$1=$ Very Poor $3=$ Pretty good $5=$ Very good

$2=$ Not good $\quad 4=$ Good

This questionnaire was given to 2 superiors (Rector and Deputy of Record 3), 2 colleagues (Chair of SPI and SPM), and 1 student representative. The following is the data from the processing of the PBKK performance assessment questionnaire.

Table 2. Data on Results of Processing the PBKK Performance Assessment Questionnaire

\begin{tabular}{|c|c|c|c|c|c|c|}
\hline \multirow{2}{*}{ Indicator } & & \multicolumn{5}{|c|}{ Respondents } \\
\hline & & 1 & 2 & 3 & 4 & 5 \\
\hline \multirow{3}{*}{ Work Quality } & $1 \mathrm{a}$ & 4 & 4 & 4 & 4 & 5 \\
\hline & $1 b$ & 5 & 4 & 4 & 4 & 4 \\
\hline & $1 \mathrm{c}$ & 4 & 4 & 4 & 4 & 4 \\
\hline \multirow{3}{*}{ Working Quantity } & $2 \mathrm{a}$ & 5 & 4 & 3 & 3 & 4 \\
\hline & $2 b$ & 4 & 4 & 3 & 3 & 4 \\
\hline & $2 \mathrm{c}$ & 5 & 4 & 3 & 4 & 5 \\
\hline \multirow{3}{*}{ Punctuality } & $3 a$ & 5 & 4 & 3 & 4 & 5 \\
\hline & $3 b$ & 4 & 4 & 4 & 4 & 5 \\
\hline & $3 c$ & 5 & 4 & 4 & 3 & 5 \\
\hline \multirow{3}{*}{ Work Adjustment } & $4 a$ & 5 & 4 & 5 & 4 & 3 \\
\hline & $4 b$ & 5 & 4 & 4 & 4 & 5 \\
\hline & $4 c$ & 4 & 4 & 4 & 4 & 5 \\
\hline \multirow{3}{*}{ Responsible } & $5 \mathrm{a}$ & 5 & 4 & 4 & 4 & 5 \\
\hline & $5 b$ & 5 & 4 & 4 & 4 & 5 \\
\hline & $5 \mathrm{c}$ & 5 & 4 & 4 & 4 & 5 \\
\hline \multirow{6}{*}{ Cooperation } & $6 \mathrm{a}$ & 5 & 4 & 4 & 4 & 5 \\
\hline & $6 \mathrm{~b}$ & 5 & 4 & 4 & 4 & 5 \\
\hline & $6 \mathrm{c}$ & 5 & 4 & 4 & 4 & 4 \\
\hline & $\sum$ & 85 & 72 & 69 & 69 & 83 \\
\hline & & 4.72 & 4 & 3.83 & 3.83 & 4.61 \\
\hline & $\mathbf{N a}$ & & & 4.21 & & \\
\hline
\end{tabular}

Criteria:

Very Good $\quad=5$

Good $\quad=4-4,99$

Pretty good $=3-3,99$

Not good $=2-2,99$

Very Poor $\quad=<2$ 
Based on these criteria, it can be concluded that the results of the BPKK performance appraisal are in the Good category.

\section{Conclusion}

Based on the results of the evaluation using the CIPP method, it can be concluded that the work program prepared by the PBKK is considered to be in accordance with the context, input, process, and product with the student's needs and the vision and mission the institution wants to achieve. And the performance of the PBB is in the good category after going through a performance evaluation using the 360 -degree feedback method.

\section{References}

[1] Badrujaman, A. (2011). Teori dan Aplikasi Evaluasi Program Bimbingan Konseling. Jakarta: Indeks.

[2] Candra Maulana. (2019). Evaluasi Program Layanan Informasi Dengan Model CIPP di SMP Negeri 14 Pontianak. Artikel Penelitian. Program Studi Bimbingan dan Konseling. Jurusan Ilmu Pendidikan. Fakultas Keguruan dan Ilmu Pendidikan Pontianak.

[3] Eni Rohaeni. (2018). Sistem Informasi Penilaian Kinerja Karyawan Menggunakan Metode 360 Derajat Pada STIKOM Dinamika Bangsa Jambi. Jurnal [2] vol. 12. JURNAL ILMIAH MEDIA SISFO.

[4] Widoyoko, Eko Putra. (2014). Penilaian Hasil Pembelajaran di Sekolah. Jakarta Pustaka Belajar.

[5] Mbulu, j. (1995). Evaluasi Program Konsep Dasar, Pendekatan Model, dan Prosedur Pelaksanaan, Malang: Dapartemen Pendidikan dan Kebudayaan Institut Keguruan dan ilmu Pendidikan Malang Proyek Orientasi dan Perawatan Fasilitas.

[6] Suyadi Prawirosentono. (2008). Manajemen Sumber Daya Manusia "Kebijakan Kinerja Karyawan". Yogyakarta: BPFE.

[7] Wibowo, 2011. Manajemen Kinerja. Raja Grafindo Persada, Jakarta, h. 21-25

[8] Ika Zenita Ratnaningsih. 2011 Metode Umpan Balik 360 Derajat Untuk Mengembangkan Kepemimpinan Dalam Talent Management System.

[9] Putri Rinella, 2008, Mengenal 360-degree feedback, Jurnal Teknologi Pembelajaran. 